\title{
Essential oil composition and variability of Artemisia herba-alba Asso. growing in Tunisia: comparison and chemometric investigation of different plant organs
}

\author{
Sana Bellili ${ }^{\mathrm{a}, \mathrm{b}}$, Wissal Dhifi ${ }^{\mathrm{c}}$, Abdulrahman Ben Khsif Al-Garni ${ }^{\mathrm{d}}$, Guido Flamini ${ }^{\mathrm{e}}$, Wissem Mnif ${ }^{\mathrm{a}, \mathrm{d}}$, \\ ${ }^{a}$ University Manouba, ISBST, BVBGR-LR11ES31, Biotechpole Sidi Thabet, 2020, Ariana, Tunisia. ${ }^{b}$ Faculty of Sciences of Bizerte, Jarzouna - Bizerte - \\ 7021, University of Carthage, Tunisia. ${ }^{c}$ UR Ecophysiologie Environnementale et Procédés Agroalimentaires, Biotech Pole de Sidi Thabet. Université de la \\ Manouba, Tunisie. ${ }^{\mathrm{d}}$ Faculty of Sciences and Arts in Balgarn PO BOX 60 Balgarn- Sabt Al Olaya 61985, University of Bisha, Saudi Arabia. ${ }^{\mathrm{e}}$ Department of \\ Pharmaceutical Sciences, Bioorganic Chemistry and Biopharmaceutics, University of Pisa, Via Bonanno 33, 56126, Pisa, Italy.
}

\section{ARTICLE INFO \\ Article history: \\ Received on: 27/01/2016 \\ Revised on: 03/03/2016 \\ Accepted on: 15/05/2016 \\ Available online: 28/07/2016}

\section{Key words:}

Artemisia herba-alba; GCMS; chemical variability; curcumen-15-al.

\begin{abstract}
This study was conceived to investigate the composition of four essential oils (EOs) extracted by hydrodistillation from four parts (leaves, stems, leaves/stems, roots) of Artemisia herba-alba growing wild in the Center of Tunisia. For this, Artemisia herba-alba aerial and roots parts were shade dried with ventilation at room temperature. Then, plant different parts were cut into small pieces and subjected to hydrodistillation using a Clevenger-type apparatus. The gas chromatography (GC) analyses were accomplished with a HP-5890 Series II instrument. The main results showed a total of 152 compounds detected and identified by GC and GCMS and accounting for 91.3-99.7\% of the whole oil. The four oils were characterized by the predominance of monoterpene derivatives (68.2-99.5\%) and the major volatile constituent was $\alpha$-thujone (18.2-45.5\%). Qualitative and quantitative differences between the four essential oils have been noted for some compounds. The main compounds of leaves essential oil were $\alpha$-Thujone (45.5\%), $\beta$-Thujone (11.4\%), trans-sabinyl acetate $(10.1 \%), 1,8$-Cineole $(7.4 \%)$ and camphor $(6.8 \%)$. $\alpha$-Thujone $(27.5 \%)$ was also the main compound in the essential oil of leaves/stems, followed by camphor (22.9\%), 1,8-cineole (8.3\%), $\beta$-thujone $(8.2 \%)$ and camphene (5.6\%). The essential oil of stems was dominated by $\alpha$-Thujone $(28 \%)$ followed by $\beta$-Thujone $(11.4 \%)$ and chrysantenone (11\%). In the essential oil of roots, $\alpha$-thujone was less represented (18.2\%), followed by camphor $(14.6 \%)$ and curcumen-15-al (14.3\%). It is important to mention that curcumen-15-al has been reported for the first time in Artemisia herba-alba oil Our results revealed avariability in the chemical composition and the yield of the EOs from Artemisia herba-alba. Moreover, curcumen-15-al is a new chemotype first found in Artemisia herba-alba from Tunisia.
\end{abstract}

\section{INTRODUCTION}

The genus Artemisia is one of the largest and most widely distributed genera of Asteraceae family includes 400 species (Judd et al., 2002). Artemisia species are of great socio-

\footnotetext{
* Corresponding Author

Wissem Mnif, LR11-ES31 Laboratory of Biotechnology and Valorisation of Bio-GeoRessources, Higher Institute of Biotechnology of Sidi Thabet, BiotechPole of SidiThabet, 2020, University of La Manouba, Tunisia. Email:w_mnif@yahoo.fr
}

economic thanks to their antioxidant potential besides antimicrobial and anti-parasital activities of their essential oils (Eos). Artemisia herba-alba is a medicinal and aromatic dwarf shrub that grows wild in arid and semi-arid areas of the Mediterranean basin, extending into northwestern Himalayas (Mohamed et al., 2010). In Tunisia, Artemisia herba-alba is found from the mountains around Jebel Oust to the south of the country (Mighri et al., 2009). Herbal tea from this plant has been used as analgesic, antibacterial, antispasmodic and hemostatic agents (Laid et al., 2008). 
Further, the plant is widely used in traditional medicine for the treatment of diabetes, bronchitis, diarrhea, hypertension, and neuralgias (Tahraoui et al., 2007; Mahomoodally et al., 2013). EOs of this species are known for its therapeutic disinfectant, anthelminthic and antispasmodic virtues (Hatimi et al., 2001). The aim of this paper is to provide more information on the chemical composition of the EOs extracted from different parts of A. herbaalba collected in the Center of Tunisia.

\section{MATERIAL AND METHODS}

\section{Plant material}

Artemisia herba-alba aerial (leaves and stems) and roots parts were collected from Chrarda locality in the Center of Tunisia (Fig. 1). Plant identification was carried out by Pr. MA Nabli, botanist at the Faculty of Sciences of Tunis-Tunisia. All samples were shade dried with ventilation for 15 days at room temperature. The plant used parts was cut into small pieces and subjected to hydrodistillation using a Clevenger-type apparatus (Clevenger, 1928) for $4 \mathrm{~h}$. The oil was collected and stored at $4^{\circ} \mathrm{C}$ in amber vials before analysis.

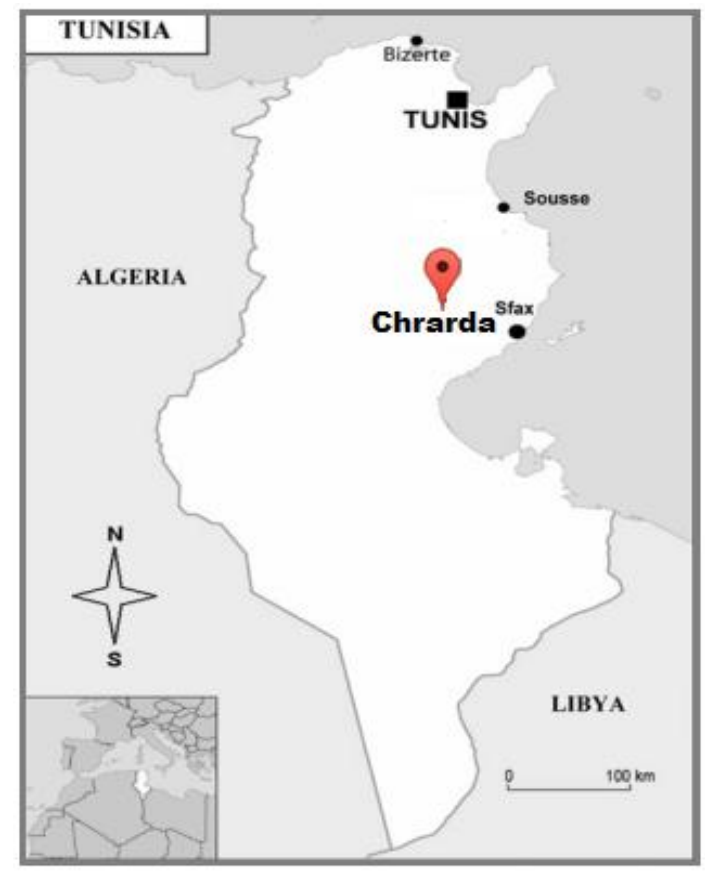

Fig 1. Origin of Artemisia herba-alba plant grown in Tunisia

\section{Gas Chromatographic-Mass Spectral Analysis}

The GC analyses were accomplished with a HP-5890 Series II instrument equipped with HP-WAX and HP-5 capillary columns $(30 \mathrm{~m} \times 0.25 \mathrm{~mm}, 0.25 \mu \mathrm{m}$ film thickness $)$. The temperature program was as follows: $60^{\circ} \mathrm{C}$ for $10 \mathrm{~min}$, ramp of $5^{\circ} \mathrm{C} / \mathrm{min}$ up to $220{ }^{\circ} \mathrm{C}$; injector and detector temperatures $250^{\circ} \mathrm{C}$; carrier gas nitrogen ( $2 \mathrm{~mL} / \mathrm{min})$; detector dual FID; split ratio 1:30; injection of $0.5 \mu \mathrm{L}$. The identification of the constituents was performed, for both columns, by comparison of their retention times with those of pure authentic samples and by mean of their linear retention indices (L.R.I) relative to the series of $n$ hydrocarbons. The relative proportions of the essential oils constituents were percentages obtained by FID peak-area normalization. GC-EIMS analyses were performed with a Varian CP- 3800 gas chromatograph equipped with a DB-5 capillary column $(30 \mathrm{~m} \times 0.25 \mathrm{~mm}$, coating thickness $0.25 \mu \mathrm{m})$ and a Varian Saturn 2000 ion trap mass detector. Analytical conditions were as follows: injector and transfer line temperature 220 and $240{ }^{\circ} \mathrm{C}$, respectively; oven temperature was programmed from 60 to 240 ${ }^{\circ} \mathrm{C}$ at $3{ }^{\circ} \mathrm{C} / \mathrm{min}$; carrier gas helium at $1 \mathrm{~mL} / \mathrm{min}$; injection of 0.2 $\mu \mathrm{L}$ (10\% hexane solution); split ratio 1:30. Identification of the constituents was based on comparison of the retention times with those of the authentic samples, comparing their L.R.I. relative to the series of $n$-hydrocarbons and on computer matching against commercial (NIST 98 and ADAMS) and home-made library mass spectra, built up from pure substances and components of known oils and MS literature data (Adams, 2009).

\section{RESULTS AND DISCUSSION}

The EO yields were respectively of $1.86 \%, 0.42 \%$, $0.25 \%$ and $0.1 \%$ for the leaves, the leaves/stems, the stems and the roots, respectively. According to Haouari and Ferchichi (2009), the oil yield varied between $0.68 \%$ and $1.93 \%$ in EOs of Artemisia herba alba growing in the South of Tunisia. The chemical composition of the analyzed oils is reported in Table 1. Altogether, 152 compounds were identified in these four EOs, accounting for $99.7 \%, 99.7 \%, 98.7 \%$ and $91.3 \%$ of the whole oils, respectively. All the EOs obtained from the different parts were characterized by a high content of $\alpha$-Thujone. It is important to announce that in the EOs of roots, $\alpha$-Thujone was less represented (18.2\%), followed by camphor (14.6\%) and curcumen-15-al (14.3\%). Curcumen-15-al has been reported for the first time in Artemisia herba-alba oil and the correspondent oil should be considered as a new chemotype. $\alpha$-Thujone has been reported as the major constituent of the Artemisia herba-alba essential oil originating from Tunisian semi-arid and south region (Akrout, 2004; Kadri et al., 2011), Jordan (Hudaib and Aburjai, 2006), Algeria (Belhatta et al., 2014), Morocco (Paolini et al., 2010) and Israel (Fleisher et al., 2002). This monoterpenic cetone confers to this plant its characteristic smell of Mentha and its bitter taste. Furthermore, leaves EO was characterized by the highest $\alpha$-Thujone amount (45.5\%). $\beta$-Thujone (11.4\%) was the second component followed by trans-sabinyl acetate $(10.1 \%), 1,8$-cineole $(7.4 \%)$, camphor $(6.8 \%)$ and isoborneol (3.4\%). The main components of this oil differed from those reported by Akrout et al. (2010), and according to them, $\beta$-Thujone was the main component of the oil extracted from the leaves of Artemisia herba-alba growing in the South of Tunisia. Furthermore, in this oil, oxygenated terpenes were the most represented compounds $(93.8 \%)$, but oxygenated monoterpenes prevailed over oxygenated sesquiterpenes $(93.3 \%$ vs. $0.5 \%$, respectively). Terpene hydrocarbons were present in lower amount $(5.7 \%)$ divided between monoterpene $(4.6 \%)$ and sesquiterpene hydrocarbons $(1.1 \%)$. 
Haouari and Ferchichi (2009) reported that the main components were cineole, thujones, chrysanthenone, camphor, borneol, chrysanthenyl acetate, sabinyl acetate, davana ethers and davanone in Eos of Artemisia herba alba growing in the South of Tunisia. They also reported Twelve samples characterized by monoterpenes as major components amounting to more than $57 \%$ of the total oil, three had last three samples had approximately the same percentage of monoterpenes and sesquiterpenes.

In addition, non-terpene oxygenated compounds were scarcely detected $(0.2 \%$ for ( $z$-Jasmone) and phenylpropanoids were present only in traces (eugenol and methyl eugenol). In the EO of leaves/stems, the main compounds were $\alpha$-Thujone (27.5\%) and camphor $(22.9 \%)$ followed by 1,8 -cineole $(8.3 \%), \beta$-Thujone $(8.2 \%)$ and camphene $(5.6 \%)$. It should be noted that camphor had the highest percentage in this oil. Also, in this oil, oxygenated monoterpenes represented the main constituents $(87.4 \%)$ whereas monoterpene hydrocarbons were more represented, in particular bicyclic monoterpenes $(9.7 \%)$, but their percentage $(12.1 \%)$ was considerably lower than that of oxygenated monoterpenes. On the other hand, sesquiterpenes were particularly absent, either as hydrocarbons (only present as trace amounts) or oxygenated derivatives $(0.2 \%$ for globulol). Non-terpene oxygenated compounds were detected only in trace amounts.

Table 1: Composition (in $\%$ of the total identified EO) a of the essential oils of leaves, leaves/stems, stems and roots of Artemisia herba-alba from center Tunisia.

\begin{tabular}{|c|c|c|c|c|c|}
\hline Constituents & تُ & 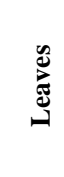 & 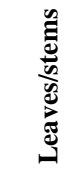 & $\stackrel{\mathscr{J}}{\tilde{J}}$ & $\begin{array}{l}\mathscr{n} \\
\stackrel{0}{0}\end{array}$ \\
\hline (E)-2-Hexenal & 855 & $\mathrm{-c}^{\mathrm{c}}$ & - & 0.2 & 0.2 \\
\hline (Z)-Salvene & 856 & 0.7 & - & - & - \\
\hline (E)-Salvene & 867 & $\operatorname{tr}$ & - & - & - \\
\hline$n$-Hexanol & 868 & - & $\operatorname{tr}^{\mathrm{d}}$ & $\operatorname{tr}$ & 0.2 \\
\hline Heptanal & 900 & - & - & - & $\operatorname{tr}$ \\
\hline Tricyclene & 928 & 0.2 & 0.1 & $\operatorname{tr}$ & $\operatorname{tr}$ \\
\hline$\alpha$-Thujene & 932 & $\operatorname{tr}$ & 0.3 & $\operatorname{tr}$ & - \\
\hline$\alpha$-Pinene & 939 & - & 0.4 & 0.3 & - \\
\hline Camphene & 954 & 1.5 & 5.6 & 0.8 & 1.5 \\
\hline Thuja-2,4(10)-diene & 957 & $\operatorname{tr}$ & $\operatorname{Tr}$ & - & - \\
\hline Benzaldehyde & 962 & - & - & $\operatorname{tr}$ & 0.2 \\
\hline Heptanol & 970 & - & $\operatorname{Tr}$ & $\operatorname{tr}$ & $\operatorname{tr}$ \\
\hline Sabinene & 977 & 1.2 & 3 & 0.6 & 0.7 \\
\hline$\beta$-Pinene & 980 & 0.2 & 0.4 & 0.1 & - \\
\hline 6-methyl-5-hepten-2-one & 986 & - & - & $\operatorname{tr}$ & $\operatorname{tr}$ \\
\hline 3-Octanone & 988 & $\operatorname{tr}$ & $\operatorname{Tr}$ & - & - \\
\hline cis-meta-mentha-2,8-diene & 987 & - & - & - & 0.3 \\
\hline dehydro-1,8-Cineole & 991 & $\operatorname{tr}$ & - & - & - \\
\hline Myrcene & 993 & 0.2 & 0.2 & - & - \\
\hline 3-Octanol & 994 & $\operatorname{tr}$ & $\operatorname{Tr}$ & - & - \\
\hline Mesitylene & 996 & - & - & $\operatorname{tr}$ & - \\
\hline Yomogi alcohol & 999 & $\operatorname{tr}$ & - & - & - \\
\hline$\alpha$-Phellandrene & 1005 & - & - & $\operatorname{tr}$ & - \\
\hline$\alpha$-Terpinene & 1019 & 0.2 & 0.4 & 0.1 & $\operatorname{Tr}$ \\
\hline p-Cymene & 1028 & 0.4 & 1 & 0.5 & 0.4 \\
\hline 1,8-Cineole & 1034 & 7.4 & 8.3 & 1.7 & 3 \\
\hline Santolina alcohol & 1040 & $\operatorname{tr}$ & - & - & - \\
\hline Lavender lactone & 1042 & - & - & - & $\operatorname{Tr}$ \\
\hline Phenyl Acetylaldehyde & 1044 & - & $\operatorname{Tr}$ & $\operatorname{tr}$ & 0.3 \\
\hline (E)- $\beta$-Ocimene & 1051 & - & $\operatorname{Tr}$ & - & - \\
\hline
\end{tabular}

\begin{tabular}{|c|c|c|c|c|c|}
\hline$\gamma$-Terpinene & 1062 & 0.4 & 0.6 & 0.2 & 0.2 \\
\hline Artemisia ketone & 1065 & $\operatorname{tr}$ & - & - & - \\
\hline cis-Sabinene hydrate & 1069 & 0.2 & 0.5 & 0.4 & 0.4 \\
\hline$n$-Octanol & 1071 & - & $\operatorname{tr}$ & - & $\operatorname{Tr}$ \\
\hline cis-Linalool oxide & 1075 & $\operatorname{tr}$ & $\operatorname{tr}$ & $\operatorname{tr}$ & 0.4 \\
\hline Artemisia alcohol & 1086 & $\operatorname{tr}$ & - & - & - \\
\hline Terpinolene & 1089 & $\operatorname{tr}$ & 0.1 & 0.1 & $\operatorname{Tr}$ \\
\hline 6,7-epoxy Myrcene & 1090 & - & $\operatorname{tr}$ & - & - \\
\hline trans-Linalool oxide & 1094 & $\operatorname{tr}$ & - & - & - \\
\hline trans-Sabinene hydrate & 1098 & 0.2 & 0.5 & 0.6 & 0.7 \\
\hline Linalool & 1100 & $\operatorname{tr}$ & $\operatorname{tr}$ & - & - \\
\hline$\alpha$-Thujone & 1103 & 45.5 & 27.5 & 28 & 18.2 \\
\hline 1-Octen-3-yl acetate & 1113 & - & $\operatorname{tr}$ & - & - \\
\hline$\beta$-Thujone & 1116 & 11.4 & 8.2 & 11.4 & 5.7 \\
\hline cis-p-menth-2-en-1-ol & 1122 & - & 1.5 & 1.4 & 1.7 \\
\hline trans-Pinene hydrate & 1123 & $\operatorname{tr}$ & - & - & - \\
\hline Chrisanthenone & 1125 & 0.5 & 0.7 & 11 & 1.6 \\
\hline Dihydro Sabina ketone & 1126 & 0.7 & - & - & - \\
\hline cis-Limonene oxide & 1135 & - & $\operatorname{tr}$ & - & - \\
\hline (iso)-3-Thujanol & 1138 & $\operatorname{tr}$ & $\operatorname{tr}$ & $\operatorname{tr}$ & - \\
\hline trans-Pinocarveol & 1140 & 2.4 & 2.7 & 4.3 & 3.6 \\
\hline Terpinen-1-ol & 1143 & - & - & - & $\operatorname{Tr}$ \\
\hline Camphor & 1144 & 6.8 & 22.9 & 8 & 14.6 \\
\hline (neo-iso)-3-Thujanol & 1152 & $\operatorname{tr}$ & - & - & - \\
\hline (neo)-3-Thujanol & 1154 & - & $\operatorname{tr}$ & $\operatorname{tr}$ & $\operatorname{Tr}$ \\
\hline Sabina ketone & 1156 & 0.2 & 0.3 & 0.2 & 0.2 \\
\hline Isoborneol & 1158 & - & 2.8 & 2.7 & 2.5 \\
\hline Pinocarvone & 1166 & 0.5 & 1.1 & 2.3 & 1.1 \\
\hline Borneol & 1169 & 3,4 & - & - & - \\
\hline 1-Nonanol & 1172 & - & - & $\operatorname{tr}$ & $\operatorname{Tr}$ \\
\hline cis-Pinocamphone & 1174 & - & $\operatorname{tr}$ & $\operatorname{tr}$ & $\operatorname{Tr}$ \\
\hline 4- Terpineol & 1178 & 0.9 & 1.4 & 0.9 & 1.3 \\
\hline Naphtalene & 1180 & - & - & - & 0.7 \\
\hline a-Thujenal & 1182 & $\operatorname{tr}$ & 0.2 & 0.3 & $\operatorname{Tr}$ \\
\hline$\alpha$-Terpineol & 1190 & $\operatorname{tr}$ & 0.2 & 0.2 & 0.3 \\
\hline cis-Piperitol & 1194 & - & - & 0.7 & 0.4 \\
\hline Myrtenal & 1195 & 0.4 & 0.6 & - & 0.5 \\
\hline Myrtenol & 1196 & $\operatorname{tr}$ & - & - & - \\
\hline trans-Piperitol & 1205 & 0.3 & 0.9 & 2 & 1.7 \\
\hline$\gamma$-Terpineol & 1207 & $\operatorname{tr}$ & - & 0.1 & 0.2 \\
\hline Vebrenone & 1214 & $\operatorname{tr}$ & - & - & - \\
\hline trans-Carveol & 1221 & $\operatorname{tr}$ & $\operatorname{tr}$ & $\operatorname{tr}$ & $\operatorname{Tr}$ \\
\hline Citronellol & 1229 & - & - & - & 0.3 \\
\hline cis-Carveol & 1233 & $\operatorname{tr}$ & - & - & - \\
\hline Phenol,2-ethyl-6-methyl & 1236 & $\operatorname{tr}$ & - & - & - \\
\hline cis-Ascaridole & 1237 & - & $\operatorname{tr}$ & $\operatorname{tr}$ & - \\
\hline Cuminaldehyde & 1240 & 0.2 & 0.2 & 0.3 & $\operatorname{Tr}$ \\
\hline Carvone & 1243 & $\operatorname{tr}$ & 0.3 & 0.3 & 0.7 \\
\hline Carvotanacetone & 1247 & $\operatorname{tr}$ & $\operatorname{tr}$ & $\operatorname{tr}$ & - \\
\hline Piperitone & 1258 & 0.4 & 1.5 & 2.1 & 3.3 \\
\hline Bornyl acetate & 1260 & 0.2 & - & - & - \\
\hline cis-Chrysanthenyl acetate & 1263 & 0.5 & 0.1 & 1.1 & 0.3 \\
\hline Geranial & 1278 & - & $\operatorname{tr}$ & - & - \\
\hline Isobornyl acetate & 1285 & 0.7 & 0.7 & 0.8 & 0.4 \\
\hline trans-Sabinyl acetate & 1291 & 10.1 & 4.3 & 7.2 & 2.4 \\
\hline trans-Pinocarvyl acetate & 1296 & $\operatorname{tr}$ & - & - & - \\
\hline Terpinen-4-ol acetate & 1300 & - & $\operatorname{tr}$ & 0.1 & - \\
\hline Carvacrol & 1301 & $\operatorname{tr}$ & $\operatorname{tr}$ & 0.1 & $\operatorname{Tr}$ \\
\hline Iso-Ascaridole & 1303 & $\operatorname{tr}$ & $\operatorname{tr}$ & $\operatorname{tr}$ & - \\
\hline $\begin{array}{l}\text { 6-Hydroxy } \\
\text { carvotanacetone }\end{array}$ & 1311 & - & $\operatorname{tr}$ & 0.3 & $\operatorname{Tr}$ \\
\hline cis-Pinocarvyl acetate & 1312 & $\operatorname{tr}$ & - & - & - \\
\hline Myrtenyl acetate & 1327 & $\operatorname{tr}$ & $\operatorname{tr}$ & - & - \\
\hline$\alpha$-Terpinyl acetate & 1352 & $\operatorname{tr}$ & - & - & - \\
\hline Eugenol & 1361 & $\operatorname{tr}$ & - & $\operatorname{tr}$ & - \\
\hline$\alpha$-Copaene & 1376 & $\operatorname{tr}$ & $\operatorname{tr}$ & $\operatorname{tr}$ & - \\
\hline$\beta$-Maaliene & 1380 & - & - & $\operatorname{tr}$ & $\operatorname{Tr}$ \\
\hline$\alpha$-Isocomene & 1386 & - & - & $\operatorname{tr}$ & $\operatorname{Tr}$ \\
\hline (E)-Jasmone & 1391 & - & - & $\operatorname{tr}$ & - \\
\hline (Z)-Jasmone & 1393 & 0.2 & $\operatorname{tr}$ & 0.6 & 0.2 \\
\hline Methyl Eugenol & 1404 & $\operatorname{tr}$ & - & $\operatorname{tr}$ & - \\
\hline$\beta$-Isocomene & 1407 & - & - & $\operatorname{tr}$ & - \\
\hline$\alpha$-Gurjunene & 1409 & - & - & - & $\operatorname{Tr}$ \\
\hline
\end{tabular}




\begin{tabular}{|c|c|c|c|c|c|}
\hline$\beta$-Caryophyllene & 1418 & $\operatorname{tr}$ & - & - & - \\
\hline$p$-Cymen-7-ol acetate & 1423 & - & $\operatorname{tr}$ & $\operatorname{tr}$ & - \\
\hline (E)-Geranyl acetone & 1454 & - & - & - & $\operatorname{Tr}$ \\
\hline Alloaromadendrene & 1461 & - & $\operatorname{tr}$ & $\operatorname{tr}$ & - \\
\hline$\beta$-Chamigrene & 1475 & $\operatorname{tr}$ & $\operatorname{tr}$ & - & $\operatorname{Tr}$ \\
\hline Germacrene D & 1480 & 0.7 & $\operatorname{tr}$ & 0.2 & $\operatorname{Tr}$ \\
\hline (E)- $\beta$-Ionone & 1485 & - & - & - & 0.2 \\
\hline$\beta$-Silinene & 1489 & $\operatorname{tr}$ & - & - & - \\
\hline Valencene & 1492 & - & - & - & $\operatorname{Tr}$ \\
\hline Bicyclogermacrene & 1494 & 0.4 & $\operatorname{tr}$ & 0.2 & - \\
\hline trans- $\gamma$-Cadinene & 1513 & - & $\operatorname{tr}$ & - & $\operatorname{Tr}$ \\
\hline Cubebol & 1515 & - & - & 0.2 & - \\
\hline$\beta$-Curcumene & 1516 & $\operatorname{tr}$ & - & - & - \\
\hline$\delta$-Cadinene & 1524 & $\operatorname{tr}$ & $\operatorname{tr}$ & - & - \\
\hline Italicene epoxide & 1549 & - & - & $\operatorname{tr}$ & - \\
\hline Ledol & 1565 & - & $\operatorname{tr}$ & - & - \\
\hline trans-Nerolidol & 1566 & $\operatorname{tr}$ & - & 0.3 & - \\
\hline Germacrene D-4-ol & 1574 & - & - & $\operatorname{tr}$ & - \\
\hline Spathulenol & 1576 & 0.5 & $\operatorname{tr}$ & 1.5 & 0.6 \\
\hline Caryophyllene oxide & 1581 & $\operatorname{tr}$ & $\operatorname{tr}$ & 0.5 & 0.6 \\
\hline Globulol & 1583 & - & 0.2 & - & 0.5 \\
\hline Viridiflorol & 1590 & - & - & 0.3 & - \\
\hline$\beta$-Copaen-4- $\alpha$-ol & 1591 & $\operatorname{tr}$ & $\operatorname{tr}$ & 0.4 & 0.2 \\
\hline Carotol & 1594 & - & - & 0.4 & - \\
\hline epi Cedrol & 1596 & - & - & 0.2 & 0.4 \\
\hline Humulene epoxide II & 1607 & $\operatorname{tr}$ & - & - & - \\
\hline$\beta$-Himachalene oxide & 1616 & - & - & 0.2 & - \\
\hline epi-10- $\gamma$-Eudesmol & 1620 & - & - & - & 0.2 \\
\hline 1-epi-Cubenol & 1628 & $\operatorname{tr}$ & $\operatorname{tr}$ & - & 0.2 \\
\hline 5-Cedranone & 1630 & - & - & 0.1 & - \\
\hline$\gamma$-Eudesmol & 1631 & - & - & - & 0.2 \\
\hline$\beta$-Cedren-9-one & 1632 & - & - & 0.4 & - \\
\hline $\begin{array}{l}\text { Epoxy-Allo- } \\
\text { Aromadendrene }\end{array}$ & 1634 & $\operatorname{tr}$ & - & - & 0.2 \\
\hline Cubenol & 1641 & - & - & 0.3 & - \\
\hline Tau-Cadinol & 1642 & - & $\operatorname{tr}$ & 0.3 & 0.3 \\
\hline$\beta$-Eudesmol & 1649 & $\operatorname{tr}$ & - & $\operatorname{tr}$ & 0.4 \\
\hline Selin-11-en- $4 \alpha$-ol & 1652 & - & - & - & 0.2 \\
\hline$\alpha$-Eudesmol & 1654 & $\operatorname{tr}$ & - & $\operatorname{tr}$ & - \\
\hline$\alpha$-Cadinol & 1655 & - & - & - & 0.6 \\
\hline Valerianol & 1658 & - & - & 0.2 & - \\
\hline Valeranone & 1675 & - & - & 0.3 & 0.5 \\
\hline Ishwarone & 1682 & - & - & 0.2 & - \\
\hline Acorenone & 1693 & - & - & 0.2 & 0.4 \\
\hline Germacrone & 1694 & - & - & 0.3 & 0.2 \\
\hline Mayurone & 1710 & - & - & - & 0.5 \\
\hline Curcumen-15-al & 1713 & - & - & 0.3 & 14.3 \\
\hline Cyclocolorenone & 1761 & - & - & $\operatorname{tr}$ & 0.3 \\
\hline Benzyl benzoate & 1763 & - & - & $\operatorname{tr}$ & - \\
\hline 14-oxy- $\alpha$-Muurolene & 1769 & - & - & $\operatorname{tr}$ & - \\
\hline Heneicosane & 2100 & - & - & - & 0.3 \\
\hline Total identified $(\%)$ & & 99.7 & 99.7 & 98.7 & 91.3 \\
\hline
\end{tabular}

Stems EO was characterized by the predominance of $\alpha$ Thujone (28\%). $\beta$-Thujone and chrysanthenone were detected in similar amounts $(11.4 \%$ and $11 \%$, respectively). camphor and trans-sabinyl acetate were detected at significant amounts (8 and $7.2 \%$ respectively). Chrysanthenone was found at its highest percentage; however it was scarcely represented in the other EOs with an amount varying from $0.5 \%$ to $1.6 \%$. Also, in the stems, monoterpenes were the main class of volatiles $(91.2 \%)$, followed by sesquiterpenes $(6.7 \%)$ and no terpenic oxygenated $(0.8 \%)$. Among monoterpenes, oxygenated ones were more abundant than hydrocarbons $(88.5 \%$ vs. $2.7 \%$, respectively). Also among sesquiterpenes, oxygenated derivatives were detected in higher percentage $(6.3 \%)$ than hydrocarbons ones (0.4\%). Phenylpropanoids and no terpenic hydrocarbons were represented in traces.

The EO of roots was dominated by $\alpha$-Thujone whose amount was lower than in the other oils (18.2\%). Besides, this oil was characterized by high camphor and curcumen-15-al percentages $(14.6 \%$ and $14.3 \%$, respectively). It seems that curcumen-15-al was exclusive of EO; however it was detected only in very small amount in the stems $(0.3 \%)$. It should be noted that this oil type was not reported in literature because. It is reported at the first time that such codominance of 3 main components of $\alpha$-thujone, camphor and curcumen-15-al has been reported in Artemisia herba-alba oils. Curcumen-15-al should be considered as a new chemotype of Artemisia herba-alba. Like $\alpha$ thujone, $\beta$ - thujone was found with a lower percentage than that found in the others examined oils (5.7\% vs. $11.4 \%$ and $8.2 \%$ ).

Comparing the four EOs, monoterpenes had the highest amounts in leaves/stems (99.5\%), followed by leaves (97.9\%), stems $(91.2 \%)$ and roots $(68.2 \%)$. Among studied oragns, leaves accumulated the highest amount of oxygenated monoterpenes (93.3\%). For sesquiterpenes, the most important percentages were detected in roots $(20.8 \%)$, followed by stems $(6.7 \%)$, leaves $(1.6 \%)$ and leaves/stems $(0.2 \%)$. Furthermore, the highest value of oxygenated sesquiterpenes was found in the roots $(20.8 \%)$.

\section{CONCLUSION}

Artemisia herba-alba EOs were characterized by qualitative and quantitative differences depending on the part of the plant. The variability was especially related to the proportions of constituents and relatively to the presence of new compounds or the absence of particular ones. It has been suggested that the variation in EO yield and the composition could be due to the activity of enzymes responsible for the biosynthesis of volatile oils (Hendawy and Khaled, 2005).

According to our results, it seems that chemical composition of Artemisia herba-alba essential oil varied significantly with the part of the plant. This characteristic should contribute to the understanding of the pharmacological activities of the herb. Furthermore, it must be taken into account when the plant could be used as aroma source and also in its valorization in many industrial sectors in relation to the type of volatiles accumulated.

\section{COMPETING INTERESTS} interests.

The authors declare that they have no competing

\section{ACKNOWLEDGEMENTS}

This study was funded by the Tunisian Ministry of Higher Education and Scientific Research. Thanks are also to Dr. Sharif Mohammad Shahidullah from Department of English, 
Faculty of Sciences and Arts in Balgarn, University of Bisha, Saudi Arabia for his contribution in the correction of English language.

\section{REFERENCES}

Adams RP. 2009. Identification of Essential Oil Components by Gas Chromatography/Mass Spectrometry (4th ed). Allured Publishing Co., Carol Stream, IL: USA.

Akrout A. Essential oil study of some pastoral plants from.Matmata (south Tunisia) [in French]. Cah. Options. Med, 2004; 62: 289-292.

Akrout A, El Jani H, Amouri S, Neffati M. Screening of antiradical and antibacterial activities of essential oils of Artemisia campestris L., Artemisia herba alba Asso, and Thumus capitatus Hoff. Et Link. Growing wild in the southern of Tunisia. Recent Res. Sci. Technol, 2010; 2: 29-39.

Belhatta R, Amor L, Barroso JG, Pedro LG, Figueiredo CA. Essential oil from Artemisia herba-alba Asso grown wild in Algeria: Variability assessment and comparison with an updated literature survey. Arabian Journal of Chemistry, 2014; 7: 243-251.

Clevenger JF. Apparatus for the determination of volatile oil. J. Am. Pharm. Assoc, 1928; 17: 346-349.

Fleisher Z, Fleisher A, Nachbar RB. Chemovariation of Artemisia herba-alba Asso. Aromatic plants of the Holy Land and the Sinai. Part XVI. J. Essent. Oil. Res, 2002; 14: 156-160.

Haouari $\mathrm{M}$ and Ferchichi A. Essential oil composition of Artemisia herba-alba from Southern Tunisia. Molecules, 2009; 14:15851594.

Hatimi S, Boudouma M, Bichichi M, Chaib N, Idrissi NG. Evaluation in vitro de l'activité antileishmanienne d'Artemisia herba-alba Asso. Thérapeutique, Bulletin de la Société de pathologie exotique, 2001; 94: 29-31.

Hendawy SF, Khalid KA. Response of sage (Salvia officinalis L.) plants to zinc application under different salinity levels. J. Applied Sci. Res, 2005; 1: 147-155.

Hudaib M, Aburjai T. Composition of the Essential Oil from Artemisia herba-alba Grown in Jordan. J. Essent. Oil. Res, 2006; 18: 301304.
Judd WS, Campbell CS, Kellogg EA, Stevens PF, Donoghue MJ. 2002. Plant systematics: a phylogenetic approach (2nd ed.) Sinauer Associates Inc., USA.

Kadri A, Chobba IB, Zarai Z, Bekir A, Gharsallah N, Damak M, Gdoura R. Chemical constituents and antioxidant activity of the essential oil from aerial parts of Artemisia herba-alba grown in Tunisian semi-arid region. African Journal of Biotechnology, 2011; 10: 2923-2929.

Laid M, Hegazy MEF, Ahmed AA. Sesquiterpene lactones from Algerian Artemisia herba-alba. Phytochem. Lett, 2008; 1:85-88.

Mahomoodally FM. 2013. Traditional Medicines in Africa: An Appraisal of Ten Potent African Medicinal Plants. Evidence-Based Complementary and Alternative Medicine. ID 617459. http://dx.doi.org/10.1155/2013/617459.

Mighri H, Akrout A, Neffati M, Tomi F, Casanova J. The essential oil from Artemisia herba-alba Asso cultivated in Arid Land (South Tunisia). J. Essent. Oil Res, 2009; 21: 453-456.

Mohamed AH, El-Sayed MA, Hegazy ME, Helaly SE, Esmail AM, Mohamed NS, Chemical Constituents and Biological Activities of Artemisia herba-alba. Rec. Nat. Prod, 2010; 4: 1-25.

Paolini J, Ouariachi EME, Bouyanzer A, Hammouti B, Desjobert JM, Costa J, Muselli A. Chemical variability of Artemisia herba-alba Asso essential oils from East Morocco. Chem. Pap, 2010; 64: $550-556$

Tahraoui A, El-Hilaly J, Israili ZH, Lyoussi B. Ethnopharmacological survey of plants used in the traditional treatment of hypertension and diabetes in south-eastern Morocco (Errachidia province) J. of Ethnopharmacol, 2007; 110: 105-117.

\section{How to cite this article:}

Bellili S, Dhifi W, Al-Garni ABK, Flamini G, Mnif W. Essential oil composition and variability of Artemisia herba-alba Asso. growing in Tunisia, comparison and chemometric investigation of different plant organs. J App Pharm Sci, 2016; 6 (07): 038-042. 